\title{
Indonesian's Industrial Decission on Self-Generated Electricity
}

Adi Setiya Dwi Grahito

Indonesian Institute of Sciences, Jakarta, Indonesia

Corresponding author. Email: adisetiya@gmail.com

Submitted: 202 1-03-2 1 | Accepted: 202 1-04-26 | Published: 202 1-04-30

\begin{abstract}
This study analyzes the factors that determine firms' decisions on self-generated electricity in Indonesia. Specifically, I explore the difference in industries' decisions making across Indonesian five major islands in the past ten years. The empirical investigation utilizes Indonesian's Large and Medium Firm dataset of the years 2004, 2009, and 2014 from Indonesian Statistics. The empirical results show that an industry with higher output, higher income, and less labor is positively associated with the probability of having a selfgenerated electricity. Moreover, for firms that located in Kalimantan and Papua/Nusa Tenggara/Maluku island, they have a higher probability $(24.7 \%$ and $19.8 \%$, in comparison with Jawa/Bali island) of the self-generated electricity. The industry that plays in agriculture sector is also more likely to self-generate electricity. The year effect on the study indicates that in 2009 the industries reduce the usage of self-generated electricity. All of these findings are robust across different model specifications.
\end{abstract}

Keywords: inequality in electricity, self-generated energy, manufacture, industrial's strategy, spatial characteristic 


\title{
Indonesian’s Industrial Decission on Self-Generated Electricity
}

\author{
Adi Setiya Dwi Grahito
}

\section{Introduction}

Indonesia, the world's largest island country, lies along the equator line. It resides of more than 17,000 islands that about 6,000 of these islands are prohibited. About 267 million people have settled on the main islands, which are including Jawa, Bali, Sumatra, Kalimantan, Maluku, Nusa Tenggara, and Papua. These geographical features, on the one hand, give many opportunities in terms of tourism, natural biodiversity, social and culture enrichment, and many other benefits. However, on the other hand, it makes the Indonesian government have difficulties in terms of giving equal public needs, one of the public facilities that urgent is electricity.

Electricity is one of the backbones of the public infrastructure that the government should widely provide to elevate the economy. Moreover, electricity is the general needs that give benefit not only the household but also the industry. In Indonesia, the electricity generation operated by a state-owned company, PT Perusahaan Listrik Negara (PLN). As a company that should connect the electricity for a thousand islands with diverse topography, PLN's primary responsibilities still far from done. According to the report of International Energy Agency (2017), the variety of the living location become one of the challenging issues for each southeast Asia member countries in terms of distributing the electricity across the nation. For this reason, PLN is still struggling with the government's target: $100 \%$ electrification in 2030.

Grid, network distribution of electricity, is also one of the responsibilities that PLN should maintain to provide the power for both households and industries. On-grid and off-grid are a common term for households or industries that connect or not connect to the electricity line. A firm usually has two options to power up its production line: connect to the grid or self-generate its electricity.

Speaking of the medium and large industrial sectors, they play an essential contribution to the economy. Industries not only by attracting a large number of workers but also by giving a higher tax to the government. In Indonesia, the medium and large industry divided by several sectors based on their industrial activities. In this study, it only employs six industrial sectors.

Agriculture \& Plantation sector holds the industry that focuses on farming and its derivative products, such as Crude Palm Oil (CPO), pulp and paper, or those who provide the raw material for foods or other industrial sectors. However, for Chemical, Metal, \& Mining Processing are an industrial sector that is mostly producing chemical substances, pharmacies, provide or process metal-related material, coal mining, oil refineries, and another related topic.

Industries under the Mechanical, Electrical, \& Automotive Parts sector are mostly producing electronics, building engines, repairing the engine, manufacturing the transportation means, or delivering the automotive supplies for other industries. For 
industries under the Food, Drink, and Tobacco sector, these mostly consist of industries that producing the food, edible processing material, selling drinking and beverages, processing tobacco, producing cigarettes, or others.

For industries under the Textile and Wearing sector, they mostly work on processing the textile, producing the clothes, shoes, bags, and others. Lastly, the other industry sector contains several mixed kinds of areas such as furniture producers, printing services, publishing businesses, or media-related businesses.

Medium and large industries, the fundamental element in terms of contributing to economic push and reducing unemployment, highly depends on this electricity supply. Compared to another consumer in Indonesian, this sector becomes the highest growth of energy consumption in the period 1990-2007, roughly 6.3\% per annum (ASEAN Center for Energy, 2011). With most of the development of infrastructure focus on Jawa and Bali island, the other islands may get lag behind. Furthermore, the industries will likely choose the resourceful island as the place to establish their production. As a result, not only the Jawa and Bali excels in construction and public services, but also in terms of social inequality. It also could lead to the migration of skilled and educated labor for gainfully employed.

This paper attempts to address the industrial point of view in terms of self-generated electricity between each island in Indonesia, where the discussion on this topic is still limited. By focusing on the island as the main subject, it will be a better fundamental step for the related stakeholders to implement further regulation toward the issue.

Where most of the inequality studies are often examined in money-associated terms such as income, consumption, and another monetary-related measurement, this study shows detailed information about how Indonesian firm behavior according to the data responding to the availability of the electricity infrastructure. The regional information included in the study also helps to explicate the island characteristics that may lead to different policies regarding providing the electricity for production. Several robustness tests also done to confirm the result consistency where the difference between electricity access in regions is a minor topic in discussion. Moreover, the discussion that linked to the industrial sector is also less preferable.

In detail, this study utilizes several secondary datasets that already provided by Statistic Indonesia (BPS) and analyzed those two models using probit regression to obtain the result. The island identity then divided by five island groups, and the firms are breaking down into six industrial sectors. The firm information originates from the Large and Medium Firm survey; the island characteristics such as population, density, and Regional Gross Domestic Product (RGDP) are extracted from the macro-level dataset; and the electricity information comes from an electrical survey. Finally, all of this information categorized into three different periods of data sets: which are 2004, 2009, and 2014.

Roemer \& Trannoy (2015) briefly acquaint the inequality concept that divided into two big categories. Firstly, the inequality of opportunity. This type of inequality comes from uncontrollable circumstances, such as gender, the region of birth, and family background. It means that the first type of inequality is a given endowment of the subject of observation that could not be changed. The second type of inequality usually comes from a different level 
of subject's endeavor, for example, the level of education and a healthy lifestyle. In the firmlevel topic, all of the inequality considered a given endowment.

Shi (2019) found that his paper that there is an inequality pattern in terms of energy consumption between households in China. In terms of electricity and energy, the component of the family, such as gender, level of the region, the background of the family, and the birthplace, are crucial to the result. Specifically, the study emphasized that the location variable was a significant contributor to inequality, especially the level of region and birthplace.

Another topic in electricity inequality in household size explained by Mirnezami (2014). Based on the data, inequality occurs among households with different income or economy class. Using consumption data approximately 10,000 households in Canada, the research found that higher-income families have a higher probability of consuming more energy. The location of the household also matters to the consumption behavior: a populated place has a higher on the consumption of electricity.

In terms of HDI, a paper written by Sarkodie \& Adams (2020) revealed a relationship between HDI, inequality of household income, access to electricity, and other related variables. The given result of the paper shows that it is a positive relationship and significant between HDI and consumption.

Finding a relationship between inequality, industry, and electricity consumption in the literature is burdensome than those that using the household datasets. To be precise, few studies explore the relationship between industrial output and electrification. Most of these studies investigate the power cut or blackout that still happens and create a loss in the firm output. Some studies done by researchers (Moyo, 2012; Wu et al., 2018; Yoo \& Kim, 2006) show that power cuts have a negative and significant effect on productivity. Several of them relate the electricity shortage to turn productivity in a negative direction. Most of those studies highlight the electrification impact to the firm productivity and its output while some of them publish about the electricity cost.

Some papers discourse about the firm and its consumption behavior. Berger (Berger, 1984) found that the relationship between firm size and energy consumption. He found that smaller industries consumed more energy than the larger ones. For large enterprises, the change in the energy price had a massive impact on the cost of production. Doms \& Dunne (1995) then gave more detailed information that the firm's characteristic that is using the newer technology a more efficient in consuming energy and fossil fuel.

In terms of self-generated electricity, Perez and his colleagues in their paper (Ribó-Pérez et al., 2019) found that self-generation electricity using the photovoltaic (PV) panels decreased the demand of electricity from the grid and reduced the price through a reduction in the power of the market.

Bölük and Koç (Bölük \& Koç, 2010) investigated more comprehensive for industrial characteristic from the industrial side. They found that there are four components of the industry, which are labor, capital, intermediate input, and the electricity price affected by the changing of price electricity. By using a panel dataset from 1980 to 2001 from Turkey, they found that electricity price, capital, and labor is more elastic than other variables. For the labor side, they found that the change in the electricity price had a negative impact on the 
labor supply. At the capital side, the changing electricity price gave different results depending on the size of the industry. Most of these results explain without providing proper information about the policy to find the alternative source of energy.

\section{Data}

This study utilizes several secondary datasets that already provided by Statistic Indonesia (BPS) and analyzed those two models using probit regression to obtain the result. The island identity then divided by five island groups, and the firms are breaking down into six industrial sectors. The firm information originates from the Large and Medium Firm survey; the island characteristics such as population, density, and Regional Gross Domestic Product (RGDP) are extracted from the Indonesian macro-level dataset; and the electricity information comes from BPS electrical data survey. Finally, all of this information categorized into three different periods of data sets: which are 2004, 2009, and 2014 with total data more than 68,000 industries.

In terms of the industrial sector, the data shows a fluctuating pattern of distribution. Each category in the year of observation gives a different proportion in each year. For the agricultural-based and chemical-based industry, these two categories always show the dominant number, with a total of firms more than $20 \%$ of the total dataset.

Table 1. Distribution of observation

\begin{tabular}{llll}
\hline Distribution of observations & 2004 & 2009 & 2014 \\
\hline Number of industries per-island & $17,220(83.25)$ & $20,763(84.86)$ & $20,611(84.03)$ \\
Jawa Bali & $2,190(10.59)$ & $2,450(10.01)$ & $2,521(10.28)$ \\
Sumatra & $387(1.87)$ & $369(1.61)$ & $477(1.94)$ \\
Kalimantan & $624(3.02)$ & $581(2.38)$ & $643(2.62)$ \\
Sulawesi & $264(1.28)$ & $304(1.24)$ & $277(1.13)$ \\
Papua, Nusa Tenggara, Maluku & & & \\
Industrial sector & & & \\
Agriculture, Plantation and Rural Sector & $4,146(20.04)$ & $4,782(19.54)$ & $8,893(36.26)$ \\
Chemical, Metal, \& Mining Processing & $5,166(24.97)$ & $5,646(23.08)$ & $6,007(24.49)$ \\
Mechanical, Electrical, \& Automotive & $1,504(7.27)$ & $1,547(6.32)$ & $1,873(7.64)$ \\
Parts & & & $1,236(5.04)$ \\
Food, Drink, and Tobacco & $5,448(26.34)$ & $6,922(28.29)$ & $4,696(19.14)$ \\
Textile and Wearing Industry & $3,796(18.35)$ & $4,741(19.38)$ & $1,824(7.44)$ \\
Other Industry & $625(3.02)$ & $830(3.39)$ & \\
Source of electricity & & & $18,798(76.64)$ \\
From grid & & & $5,731(23.36)$ \\
Mixed (from grid \& self-generated) & $4,353(21.04)$ & $4,035(16.49)$ & $24,529(100)$ \\
Total & & & $24,468(100)$ \\
\hline
\end{tabular}

However, for the firm under mechanical, electrical \& automotive parts and other industry, the number of firms are likely below $10 \%$ of the overall observation. For the firm under the textile and wearing industry, it shows a stable number between 18 and $19 \%$. For the food, drink \& tobacco industry, it started at $26 \%$ in 2004 , then rose to $28 \%$ in 2009 and dropped significantly to $5 \%$ in 2014 . 
These firms are highly dependent on the electricity provided by the PLN in all year of observations. Only a small number of them that want to generate their electricity. The total number of that makes their power was about $21 \%$ in 2004, then dropped to $16 \%$ in 2009 , then rises again in 2014 that reach a peak of $23.4 \%$.

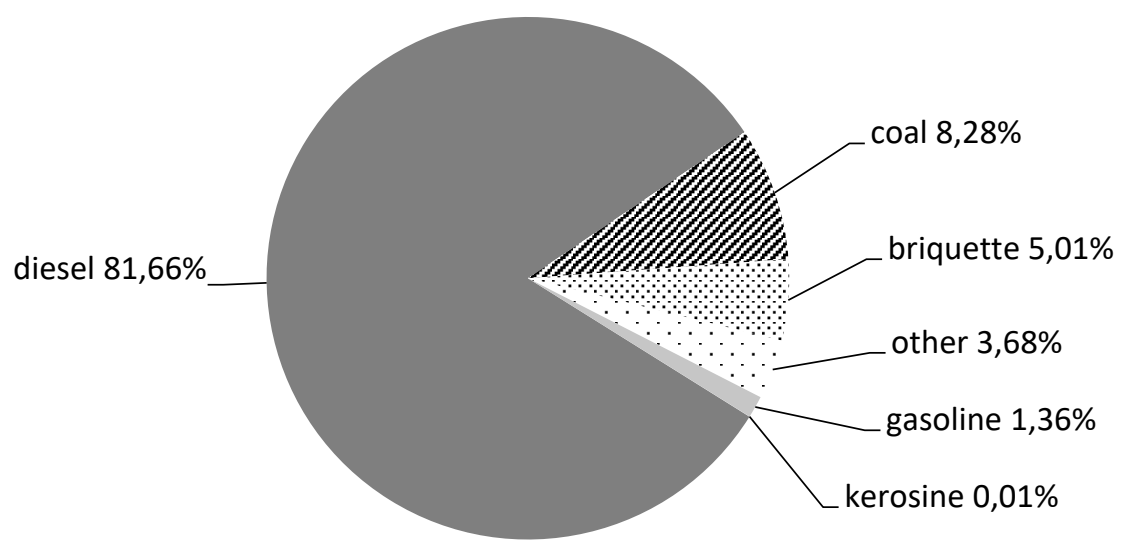

Figure 1. Comparison of the cost of fuel in all the years

Source: Statistic Indonesia, with processed

Table 2. The total cost of self-generated electricity each year, in thousand rupiahs (number of observation)

\begin{tabular}{lrrr}
\hline \multicolumn{1}{c}{ Fuel Type } & \multicolumn{2}{c}{2004} & \multicolumn{1}{c}{2009} \\
\hline Diesel & $3411,677,796(4271)$ & $4224,324,622(3759)$ & $8924,747,521(5316)$ \\
Coal & - & $195,277,287(29)$ & $1484,543,181(37)$ \\
Briquette & - & - & $1015,909,247(690)$ \\
Other & - & $747,035,231(144)$ & - \\
Gasoline & $33,778,877(629)$ & $58,036,866(600)$ & $183,040,789(1194)$ \\
Kerosene & - & $1,909,086(25)$ & \\
\hline
\end{tabular}

Source: Statistic Indonesia with processed

As explained in the Table 2, the detailed information of each fuel source is scarce. Diesel fuel shows a dominant number with the highest value in both cost and number of observations. The data indicate that several firms in the chemical, metal, mining processing, and cement industrial sector independently generate their electricity using coal and briquette. Even though the total number of firms is not as many as the gasoline 
fuel user, the cost of electricity generation is higher, especially in 2014. For firms that use kerosene and another type of fuel, the data shows that the firm rarely uses it to generate electricity. Only diesel fuel and gasoline that show availability in each year of observation.

\section{Research Methods}

This study employs a similar method developed by Bölük \& Koç (2010) to find out how a firm's characteristics have an impact on the self-generation electricity policy. It begins with the cost-based production function model that includes the four aggregate inputs: income (I), labor $(\mathrm{L})$, and output $(\mathrm{O})$. To show the effect of location and industrial sector, it assumed that the function is weakly separable. This assumption makes it easier to include the electricity (E), the location $(\mathrm{N})$, and sector $(\mathrm{S})$ information in the equation. The essential production function can be written as follow:

$$
Y=f(\text { Income, Labor, Output, Electricity, Location, Sector }) \quad \text { Eq. } 1
$$

This cost-based function widely uses in energy-related topics with industry. This method firstly developed by (Christensen et al., 1973) to explain the theory of development and industrial behavior. This theory also becomes a significant baseline for developing several kinds of researches (Berger, 1984; Bölük \& Koç, 2010; Christopoulos, 2000).

Model one in equation 2 develops using a similar empiric method (Bölük \& Koç, 2010) with some modification.

$$
\begin{gathered}
\text { havefuel }_{i}=\alpha_{0 i}+\alpha_{1} \text { logvadded }_{i}+\alpha_{2} \text { logoutput }_{i}+\alpha_{3} \text { loglabornum }_{i} \\
+\alpha_{4} \text { logepurc }+\beta \text { island }_{i}+\gamma \text { sector }_{i}+\varepsilon_{i}
\end{gathered}
$$

Where havefuel is the independent variable, which is a binary value where one means that the firm has an expenditure on the fuel to generate their electricity (self-generate) and 0 is otherwise. Despite many sources of fuel information, in this model, havefuel will only be positive if there is the cost of electricity generator, especially from gasoline and diesel fuel, according to the availability of the data. $\alpha_{0}$ is the constant, while $\alpha_{1}, \alpha_{2}, \alpha_{3}, \beta$ and $\gamma$ are the slopes of each variable.

The dependent variables divided into three categories. As the firm characteristic group, this model uses Logradded is the log of value-added cost of the firm, Logoutput is the log of the total cost of output, and Loglabornum is the log of the number of labors. The variable island is a matrix of an island group that consists of five different dummy variables, which is Island 1, island2, island3, island 4 are the variable of firm location.

This second model (equation 3) is a modification from the first model. This model is still using the havefuel as the dummy variable that gives information about the availability of the cost of alternative energy.

$$
\begin{aligned}
\text { havefuel }_{i}=\omega_{0} & +\omega_{1} \text { logvadded }_{i}+\omega_{2} \text { logoutput }_{i}+\omega_{3} \text { loglabornum }_{i} \\
& +\omega_{4} \text { logepurc }+ \text { sector }_{i}+\partial_{1} \text { hdi }_{i}+\partial_{1} \text { elcapac }_{i} \\
& +\partial_{2} \text { density }_{i}+\partial_{3} \text { rgd }_{i}+\varepsilon_{i}
\end{aligned}
$$


The differences are in the group of the independent variable. If the previous model use matrix of dummy variables to explain the island information, this model discloses the island information. It consists of island-specific details, such as the average Human Development Index (HDI), the island's proportion of the capacity of electricity, the total number of populations, and Regional Gross Domestic Product (RGDP). The other independent variables groups remain the same.

These two models will be estimated using probit regression and employ the marginal effect to understand the correlation between each variable. In the end, the study employs several different robustness methods to find out how this model can explain the data correctly.

\section{Results and Discussion}

Table 3 shows a probit regression result and marginal effect each year based on the island dummy variable. These three regressions reduce about $90 \%$ of available observations due to the availability of all variables in the model, especially the sales, capital, and capital estimation variables. Generally, this result shows a good result where every variable in each year of observation gives a significant level at $1 \%$. This number tells that the model is good enough to explain the hypotheses. The most crucial thing in this regression, all numbers in variables show a similar trend: Sumatra, Kalimantan, Sulawesi, Papua, Nusa Tenggara, Maluku show a positive result. At the same time, Jawa \& Bali island has a negative probability of all years of observation.

Table 3. Regression result of model one

\begin{tabular}{|c|c|c|c|c|c|c|}
\hline VARIABLES & $\begin{array}{l}(1) \\
\text { Probit } \\
2004 \\
\end{array}$ & $\begin{array}{l}(2) \\
\text { Margins } \\
2004 \\
\end{array}$ & $\begin{array}{l}\text { (3) } \\
\text { Probit } 2009 \\
\end{array}$ & $\begin{array}{l}(4) \\
\text { Margins } \\
2009 \\
\end{array}$ & $\begin{array}{l}\text { (5) } \\
\text { Probit } \\
2014 \\
\end{array}$ & $\begin{array}{l}(6) \\
\text { Margins } \\
2014 \\
\end{array}$ \\
\hline $\begin{array}{l}\text { Firm's revenue from } \\
\text { value-added [logvadded] }\end{array}$ & $\begin{array}{l}0.199 * \star * \\
(0.0486)\end{array}$ & $\begin{array}{l}0.0522 * \star \star \\
(0.0127)\end{array}$ & $\begin{array}{l}0.187 * \star * \\
(0.0472)\end{array}$ & $\begin{array}{l}0.0402 * \star * \\
(0.0102)\end{array}$ & $\begin{array}{l}0.415^{\star * *} \\
(0.0415)\end{array}$ & $\begin{array}{l}0.117 * \star * \\
(0.0117)\end{array}$ \\
\hline $\begin{array}{l}\text { Firm's output } \\
\text { [logouput] }\end{array}$ & $\begin{array}{l}0.244 * * * \\
(0.0471)\end{array}$ & $\begin{array}{l}0.0640 * * * \\
(0.0124)\end{array}$ & $\begin{array}{l}0.112^{\star *} \\
(0.0451)\end{array}$ & $\begin{array}{l}0.0242 * * \\
(0.00971)\end{array}$ & $\begin{array}{l}0.00527 \\
(0.0420)\end{array}$ & $\begin{array}{l}0.00148 \\
(0.0118)\end{array}$ \\
\hline $\begin{array}{l}\text { Number of labor } \\
\text { [loglabornum] }\end{array}$ & $\begin{array}{l}-0.0894 * * \\
(0.0357)\end{array}$ & $\begin{array}{l}-0.0235 * * \\
(0.00935)\end{array}$ & $\begin{array}{l}0.0320 \\
(0.0334)\end{array}$ & $\begin{array}{l}0.00690 \\
(0.00720)\end{array}$ & $\begin{array}{l}-0.177 * * * \\
(0.0288)\end{array}$ & $\begin{array}{c}-0.049 * * \\
(0.00811)\end{array}$ \\
\hline $\begin{array}{l}\text { Cost of purchasing } \\
\text { electricity from grid } \\
\text { [logepurc] }\end{array}$ & $\begin{array}{l}0.0364 * \star \\
(0.0156)\end{array}$ & $\begin{array}{l}0.00955^{* *} \\
(0.00408)\end{array}$ & $\begin{array}{l}0.0592^{* * *} \\
(0.0141)\end{array}$ & $\begin{array}{l}0.0128 * * * \\
(0.00303)\end{array}$ & $\begin{array}{l}0.0731 * * * \\
(0.0113)\end{array}$ & $\begin{array}{l}0.0206 * * \\
(0.00318 ;\end{array}$ \\
\hline Observations & 18,042 & 18,042 & 22,141 & 22,141 & 22,564 & 22,564 \\
\hline Prob > chi2 & 0 & & 0 & & 0 & \\
\hline Pseudo R2 & 0.0863 & & 0.0931 & & 0.0862 & \\
\hline
\end{tabular}

Standard errors in parentheses, variable name in square bracket

$\star \star \star \mathrm{p}<0.01, * \star \mathrm{p}<0.05, * \mathrm{p}<0.1$

Holding all variables at their mean values, the probability of firm changing their source of electricity is different from one variable to another. If compared to the other variables, the value-added income gives a more significant number of probabilities in the firm to change 
the source of electricity, especially in 2009 and 2004. For the output variable, as the proxy of the firm's output, it shows a similar trend. The probability of the firm uses alternative electricity from the grid is gradual decreases by the time of observations. It shows a significant in 2004 at $6.4 \%$ and become a lower point at roughly $2 \%$ in 2009 . It became the lowest in 2014 but insignificant in the result. Thus, it means that the firm's total expenditure gives a possibility to the firm's decision to choose the electricity, but the effect not as strong as the income.

From the point of view of the employment, by ignoring the year 2009 observation, it clear that the increasing number of labors gives a possibility to keep using the electricity from the grid. One unit of change in the number of laborers in 2004 will decrease the possibility of the firm changing the source of electricity by $2.4 \%$. Similarly, the decreasing effect also happens in 2014 at nearly $5 \%$. It refers that the bigger of the firm -in terms of labor- the bigger chance to keep using the electricity from the grid.

The logelecpurc is the variable that defines all the firm's cost of purchasing the electricity from the grid in $\log$ format. From .9\% of probability in 2004, it increases to $1.3 \%$ in the next period and reaches a higher value at $2 \%$ in 2014 . This number means as the government raises the price of electricity for the firm on one side, the firm tries to be more independent on the other side. In other words, the firm will refuse every increasing price of electricity.

\subsection{Island Analysis}

Referring to the table 4, it gives some interesting facts that the firms in Sumatra, Kalimantan, Sulawesi, Papua, Nusa Tenggara, and Maluku show random trends regarding their option of choosing the source of electricity compare to Jawa island. However, all the magnitudes are in positive in every year and every island of observation.

In 2004, for example, the marginal effect of Sumatra island started lower at 0.102, then the number reaches the maximum in 2009 at 0.128 and in 2014 roses to the highest 0.177 . It means that each year, the probability of firms that established in Sumatra to change their source of electricity is increasing if compared to Jawa island.

Table 4. Regression result of model one (cont.)

\begin{tabular}{|c|c|c|c|c|c|c|}
\hline VARIABLES & $\begin{array}{l}(1) \\
\text { Probit } \\
2004\end{array}$ & $\begin{array}{l}(2) \\
\text { Margins } \\
2004 \\
\end{array}$ & $\begin{array}{l}(3) \\
\text { Probit } \\
2009 \\
\end{array}$ & $\begin{array}{l}(4) \\
\text { Margins } \\
2009 \\
\end{array}$ & $\begin{array}{l}(5) \\
\text { Probit } \\
2014 \\
\end{array}$ & $\begin{array}{l}(6) \\
\text { Margins } \\
2014 \\
\end{array}$ \\
\hline $\begin{array}{l}\text { Sumatra island } \\
\text { [island1] }\end{array}$ & $\begin{array}{l}0.390 * \star \star \\
(0.0385)\end{array}$ & $\begin{array}{l}0.102 * \star \star \\
(0.0101)\end{array}$ & $\begin{array}{l}0.594 * \star * \\
(0.0331)\end{array}$ & $\begin{array}{l}0.128 * * * \\
(0.00715)\end{array}$ & $\begin{array}{l}0.630 * \star * \\
(0.0315)\end{array}$ & $\begin{array}{l}0.177 * \star \star \\
(0.00890)\end{array}$ \\
\hline $\begin{array}{l}\text { Kalimantan island } \\
\text { [island2] } \\
\text { Sulawesi island } \\
\text { [island } 3 \text { ] }\end{array}$ & $\begin{array}{l}0.564 * \star \star \\
(0.0806) \\
0.384 \star \star \star\end{array}$ & $\begin{array}{l}0.148 * \star * \\
(0.0212) \\
0.101 * \star \star\end{array}$ & $\begin{array}{l}0.947 * * * \\
(0.0830) \\
0.676 * * *\end{array}$ & $\begin{array}{l}0.204 * \star \star \\
(0.0180) \\
0.146 * \star \star\end{array}$ & $\begin{array}{l}0.877 * \star \star \\
(0.0740) \\
0.378 * \star \star\end{array}$ & $\begin{array}{l}0.247 * * * \\
(0.0209) \\
0.107 * * *\end{array}$ \\
\hline $\begin{array}{l}\text { Papua, Nusa Tenggara, } \\
\text { Maluku island } \\
\text { [island4] }\end{array}$ & $\begin{array}{l}(0.0623) \\
0.754 \star \star \star \\
(0.0925)\end{array}$ & $\begin{array}{l}(0.0164) \\
0.198 \star \star \star \\
(0.0243)\end{array}$ & $\begin{array}{l}(0.0629) \\
0.709 \star \star \star \\
(0.0886)\end{array}$ & $\begin{array}{l}(0.0136) \\
0.153 * \star \star \\
(0.0191)\end{array}$ & $\begin{array}{l}(0.0580) \\
0.639 \star \star \star \\
(0.0862)\end{array}$ & $\begin{array}{l}(0.0163) \\
0.180 \star \star \star \\
(0.0243)\end{array}$ \\
\hline $\begin{array}{l}\text { Observations } \\
\text { Prob > chi2 } \\
\text { Pseudo R2 }\end{array}$ & $\begin{array}{l}18,042 \\
0 \\
0.0863\end{array}$ & 18,042 & $\begin{array}{l}22,141 \\
0 \\
0.0931\end{array}$ & 22,141 & $\begin{array}{l}22,564 \\
0 \\
0.0862\end{array}$ & 22,564 \\
\hline
\end{tabular}


Similarly, the increasing slope that showed by Kalimantan data if compared to the firm on Jawa island. It starts roughly from 0.15 in 2004, then rises to 0.20 in 2009, and increases a peak in the last year of observation, at 0.25 in 2014. Even though the firms in Sulawesi island give the definite possibility to move in a similar direction, the peak of the trend of Sulawesi island data is in 2009, which is 0.15, then it dropped to 0.11 in 2014. While for Papua, Nusa Tenggara, Maluku Island, the regression result shows a v-shaped trend. It starts higher in 2004, drops in 2009, then slightly improves in 2014 but not as better as in 2004. Overall, all of this information shows that the firms on the island outer Jawa island have a possibility to change their source of electricity according to the result of the regression of model one.

For Papua and Kalimantan island results, Kalimantan shows $14.8 \%, 20.4 \%$, and $24.7 \%$, and Papua island group shows $19.8 \%, 15.3 \%$, and $18.0 \%$ for each period of observation. It clearly can be seen that the regression shows a superior result compared to other islands. It can be mean that these two islands are easy to change the source of electricity.

Several possible things lead to changing the strategy of choosing the source of electricity, especially for a firm located in outer Jawa and Bali. One of the reasons is the electrification ratio on each island. The electrification ratio is the percentage of the number of households that connected to the electricity divided by the total households in each province.

Table 5 describes the average of Electrification Ratio (ER) in each island and the difference between the current ER with national ER average in 2014, while table 5 shows a detailed in every province. The national ER average is 84.3 , which means that $84 \%$ of the household that connected to the electricity, while roughly $16 \%$ of the total households in Indonesia still not reached by the electricity. As described in the electrification ratio table above, only Jawa and Bali show a positive difference; however, the other island groups are negative. Papua, Nusa Tenggara, and Maluku are the most significant difference in terms of connectivity to the grid, about $9 \%$. This result shows a similar trend with the regression result. The low ER that maybe could lead the industries in both islands. Kalimantan and Papua island groups have a more substantial possibility to change to off-grid.

Table 5. Electrification ratio in each island in 2014

\begin{tabular}{l|c|c}
\hline Island Group & Electrification Ratio & $\begin{array}{c}\text { Differenc } \\
\text { e from } \\
\text { average }\end{array}$ \\
\hline National Average & 84.35 & 0.00 \\
Jawa \& Bali & 88.23 & 3.88 \\
Sumatra & 83.94 & -0.41 \\
Kalimantan & 80.62 & -3.74 \\
Sulawesi & 76.12 & -8.23 \\
Papua, Nusa Tenggara, Maluku & 75.37 & -8.98 \\
\hline
\end{tabular}

Source: Statistic of electricity 2016, with processing 
Table 6. Difference in Electrification Ratio in each province in each island group

\begin{tabular}{|c|c|c|c|}
\hline Island Group & Province Name & $\begin{array}{c}\text { Electrification } \\
\text { Ratio (ER) }\end{array}$ & $\begin{array}{l}\text { The difference with } \\
\text { National Average }\end{array}$ \\
\hline \multirow[t]{10}{*}{ Sumatra Island } & Bangka Belitung & 95.53 & 11.18 \\
\hline & Aceh & 92.31 & 7.96 \\
\hline & Sumatera Utara & 91.03 & 6.68 \\
\hline & Riau & 84.54 & 0.19 \\
\hline & Bengkulu & 83.47 & -0.88 \\
\hline & Lampung & 81.27 & -3.08 \\
\hline & Jambi & 80.7 & -3.65 \\
\hline & Sumatera Barat & 80.14 & -4.21 \\
\hline & Sumatera Selatan & 76.38 & -7.97 \\
\hline & Kepulauan Riau & 74.06 & -10.29 \\
\hline \multirow[t]{7}{*}{ Jawa \& Bali } & DKI Jakarta & 99.61 & 15.26 \\
\hline & Banten & 92.93 & 8.58 \\
\hline & Jawa Tengah & 88.04 & 3.69 \\
\hline & Jawa Barat & 86.04 & 1.69 \\
\hline & Bali & 85.17 & 0.82 \\
\hline & Jawa Timur & 83.55 & -0.8 \\
\hline & DI. Yogyakarta & 82.26 & -2.09 \\
\hline \multirow[t]{4}{*}{ Kalimantan } & Kalimantan Timur & 91.71 & 7.36 \\
\hline & Kalimantan Selatan & 83.75 & -0.6 \\
\hline & Kalimantan Barat & 79.77 & -4.58 \\
\hline & Kalimantan Tengah & 67.23 & -17.12 \\
\hline \multirow[t]{4}{*}{ Sulawesi } & Sulawesi Tengah & 85.53 & 1.18 \\
\hline & Sulawesi Tenggara & 85.05 & 0.7 \\
\hline & Sulawesi Selatan & 75.58 & -8.77 \\
\hline & Gorontalo & 74.11 & -10.24 \\
\hline
\end{tabular}




\begin{tabular}{|c|c|c|c|}
\hline & Sulawesi Utara & 69.64 & -14.71 \\
\hline & Sulawesi Barat & 66.78 & -17.57 \\
\hline \multirow{6}{*}{$\begin{array}{l}\text { Papua, Nusa } \\
\text { Tenggara, Maluku }\end{array}$} & Papua Barat & 90.52 & 6.17 \\
\hline & Maluku Utara & 82.28 & -2.07 \\
\hline & Papua & 77.81 & -6.54 \\
\hline & Maluku & 74.65 & -9.7 \\
\hline & Nusa Tenggara Barat & 68.05 & -16.3 \\
\hline & Nusa Tenggara Timur & 58.91 & -25.44 \\
\hline
\end{tabular}

Source: Electricity Statistics, processed

Table 7. Regression result of model one (cont.)

\begin{tabular}{|c|c|c|c|c|c|c|}
\hline VARIABLES & $\begin{array}{l}(1) \\
\text { Probit } \\
2004 \\
\end{array}$ & $\begin{array}{l}(2) \\
\text { Margins } \\
2004 \\
\end{array}$ & $\begin{array}{l}\text { (3) } \\
\text { Probit } \\
2009 \\
\end{array}$ & $\begin{array}{l}(4) \\
\text { Margins } \\
2009 \\
\end{array}$ & $\begin{array}{l}\text { (5) } \\
\text { Probit } \\
2014 \\
\end{array}$ & $\begin{array}{l}(6) \\
\text { Margins } \\
2014 \\
\end{array}$ \\
\hline $\begin{array}{l}\text { Agriculture \& } \\
\text { Plantation } \\
\text { [sectora] }\end{array}$ & $\begin{array}{l}0.0887 * \\
(0.0456)\end{array}$ & $\begin{array}{l}0.0233 * \\
(0.0120)\end{array}$ & $\begin{array}{l}0.149 * \star * \\
(0.0464)\end{array}$ & $\begin{array}{l}0.0322 * * * \\
(0.00998)\end{array}$ & $\begin{array}{l}0.216 * \star * \\
(0.0413)\end{array}$ & $\begin{array}{l}0.0609 * * * \\
(0.0116)\end{array}$ \\
\hline $\begin{array}{l}\text { Chemical, Metal, \& } \\
\text { Mining Processing } \\
\text { [sectorb] }\end{array}$ & $\begin{array}{l}-0.0111 \\
(0.0438)\end{array}$ & $\begin{array}{l}-0.00290 \\
(0.0115)\end{array}$ & $\begin{array}{l}0.100 * \star \\
(0.0444)\end{array}$ & $\begin{array}{l}0.0216^{* *} \\
(0.00957)\end{array}$ & $\begin{array}{l}0.0492 \\
(0.0385)\end{array}$ & $\begin{array}{l}0.0139 \\
(0.0109)\end{array}$ \\
\hline $\begin{array}{l}\text { Food, Drink, and } \\
\text { Tobacco [sectorc] } \\
\text { Textile and } \\
\text { Wearing Industry } \\
\text { [sectord] }\end{array}$ & $\begin{array}{l}0.0589 \\
(0.0460) \\
-0.208^{* * *} \\
(0.0478)\end{array}$ & $\begin{array}{l}0.0154 \\
(0.0121) \\
-0.0547 * \star \star \\
(0.0125)\end{array}$ & $\begin{array}{l}0.126 * * * \\
(0.0459) \\
-0.172 * * * \\
(0.0490)\end{array}$ & $\begin{array}{l}0.0270 * \star * \\
(0.00988) \\
-0.0370 * * \star \\
(0.0105)\end{array}$ & $\begin{array}{l}0.0845 * \star \\
(0.0424) \\
0.0325 \\
(0.0407)\end{array}$ & $\begin{array}{l}0.0238 * \star \\
(0.0119) \\
0.00915 \\
(0.0115)\end{array}$ \\
\hline $\begin{array}{l}\text { Others Sector } \\
\text { [sectore] }\end{array}$ & $\begin{array}{l}-0.276 * * \star \\
(0.0764)\end{array}$ & $\begin{array}{l}-0.0724 * * * \\
(0.0200)\end{array}$ & $\begin{array}{l}0.0351 \\
(0.0685)\end{array}$ & $\begin{array}{l}0.00757 \\
(0.0147)\end{array}$ & $\begin{array}{l}0.0536 \\
(0.0506)\end{array}$ & $\begin{array}{l}0.0151 \\
(0.0143)\end{array}$ \\
\hline Constant & $\begin{array}{l}-3.761^{* * *} \\
(0.117)\end{array}$ & & $\begin{array}{l}-3.497 * * * \\
(0.115)\end{array}$ & & $\begin{array}{l}-3.821^{* \star *} \\
(0.112)\end{array}$ & \\
\hline Observations & 18,042 & 18,042 & 22,141 & 22,141 & 22,564 & 22,564 \\
\hline Prob > chi2 & 0 & & 0 & & 0 & \\
\hline Pseudo R2 & 0.0863 & & 0.0931 & & 0.0862 & \\
\hline
\end{tabular}

Table 6 shows a detailed breakdown of the ER value in provinces on each island. Generally, in Jawa \& Bali island, only two of the entire provinces that still under the national average, which is DI. Yogyakarta and Jawa Timur, furthermore, these differences are not too significant if compared with other regions.

If we look closer to the detail at the province level, there are some exciting findings in Kalimantan island, for example. The negative difference happened in all provinces, but only one of them that large, more than $-15 \%$, which is Kalimantan Tengah province. That number 
contributes to the decreasing in the average ER. Similarly, in the Papua island group, the Nusa Tenggara Timur and Nusa Tenggara Barat contribute to the decreasing of the average ER with ER values about $-25 \%$ and $16 \%$, respectively. It means that in Nusa Tenggara Timur province, only $59 \%$ of the total household that already connected to the electricity grid at this period.

\subsection{Industrial Analysis}

Table 7 reveals a regression result with a dummy sector compared to the electrical, mechanical, and automotive part sector. Omitting few irrelevant results in the table, all of these variables show every firm have a possibility to change the source of electricity but for textile and other sector industry, they less likely to change the source of electricity.

Take a look closer at the result in Agriculture and Plantation, Chemical, Metal, \& Mining Processing and Food, Drink, \& Tobacco categories, the three first industrial sector show a larger value of slope than other sectors. It shows that the regression result shows a significant in $.05 \%$ and relatively more extensive slope than another sector. It means that the firms under those three sectors are likely to change their option of electricity source. These three industrial categories are the firm that mostly uses a sophisticated production line than the textile and wearing industry and other industrial sectors.

As it already explained in the descriptive statistic table, these sectors also hold as big three in term of the quantity of observation. Importantly, those firms which are under the agriculture and plantation sector have a more substantial possibility to convert their electricity source compared to the electrical, mechanical, and automotive part sector than other sectors in every year of observation.

For Agriculture and plantation sector, it starts with a little lower position at 0.02 in 2004, then roses until it reached the top at 0.06 in 2014. It means that compared to the mechanical and electrical sector, an industry that focuses on agriculture and plantation sector have a higher possibility to change their source or electricity.

Industries under chemical, metal \& mining processing also show a more substantial possibility in terms of changing their source of power, so does with industries under food, drink, and tobacco sector. Even though not as big as the agricultural industries, all of these industrial sectors show a higher possibility that the firms that take part in mechanical, electrical, and automotive parts industries.

Furthermore, for Chemical, Metal, \& Mining Processing and Food, Drink and Tobacco sectors show a more definite possibility but not as many as Agriculture and Plantation if compared to the electrical, mechanical, and automotive part sector. It means that firms under these two sectors quicker in reacting to changing their source of electricity than the Agriculture groups. The reason behind this quick-reacting could because those firms are a high technological user. It employs a more complicated production system that relies on the power of electricity than the food group.

For the textile and wearing industry, the value of significant regressions shows in 2004 and 2009 data. It gives information that the textile industries relatively keep using their source of electricity from the PLN grid. The explanation behind this result, maybe because of the textile industries in Indonesia are the labor-intensive sector that does not rely upon the 
electricity too much. It attracts many labors to work than using technology due to the affordable wage level in the country.

Moreover, most of these textile and wearing industries located in Jawa island. This decision may happen because of the easiness of getting electricity from the grid in Jawa \& Bali island. The other reason that may lead to this repeat because of the electricity capacity that always increases time by time of observation. For those firms that operate under another industrial sector, the behavior is similar to the textile industries. It shows less reacting to the changing of electricity source policy if compared to the mechanical, electrical, and automotive parts industries.

\subsection{Island's characteristic analysis}

The island characteristic analysis extracted from the regression of model 2 as shown in the table 8. This model is a modification from the first model where it is still using the data as the dummy variable that gives information about the availability of the cost of alternative energy. The significant difference is in the group of the independent variable. While the model one discloses the island with dummy variables, this model tries to replace the dummy variables with several detailed characteristic information. Those new variables are the average of Human Development Index (HDI), the island's average of the capacity of electricity, density of population, and Regional Gross Domestic Product (RGDP). The other independent variables groups remain the same.

Overall, the result remains the same trend as the result of model one. The introduced variables such as Human Development Index, Electricity capacity, island density, and Regional Gross Domestic Product (RGDP) variables are the island's characteristics where the location of the firm indicates several significant values of results. These variables will regard as external factors that may contribute to the firm's decision making in terms of selecting their source of electricity.

The Human Development Index variable is used for measuring the quality of education, healthy life, and income of people on the island. In this study, the HDI be a proxy of labor's life quality. The result shows that only in 2009 that give a weakly significant result, while in another year, the results provide a similar magnitude of probability and significance in the p-value. From the interpretation in the year 2014, we can conclude that a better quality of labor's life, it will drive the firm to keep using the electricity from PLN's grid. This result is similar to Sarkodie \& Adams (2020).

For electricity capacity, it reveals a reverse direction with the possibility of own-generating electricity. If the electricity capacity on the island increase, the firm will consider using offgrid power. This result is according to the fact and similar to the real condition.

Still related to the location of the firm, the density of the population around the firm will impact the firm's policy to use the self-generated electricity. The variable island density gives substantial information that the firm will not use its power if they were in the dense population. This regression's result also reveals the information that a dense population means better in availability in public service so that the firm will use the electricity from the grid instead of generating the electricity. 
The density variable also works as the population metering. It implies that the denser the island is, the smaller the chance the firm to utilize the self-generated electricity. This result can happen because the population density relates to the availability of land for households and firms. If the firm located on the dense island, it could be a big possibility not to use selfgenerated electricity. Furthermore, the generator for generating electricity is always made noise and releases a certain amount of air pollution. The pollution could be a negative externality that the firm should handle. This result shows a similarity with previous research done by Auffhammer \& Wolfram (2014) and Dong \& Hao (2018).

The regression's result also confirms that the wealthy of the location of the firm's establishment, the more prominent possibility of the firm to use their electricity. This information proxied by the logrgd $p$ variable. It indicates that all the variables give a similar result, which means that the firm chooses to use the electricity from the grid if the income of the region of establishment is better, the same to Mirnezami (2014). It also indicates that the size of the economy in the location firms gives a probability of changing their source of electricity.

Table 8. Regression result on model 2

\begin{tabular}{|c|c|c|c|c|c|c|}
\hline VARIABLES & $\begin{array}{l}(1) \\
\text { Probit } \\
2004\end{array}$ & $\begin{array}{l}(2) \\
\text { Margins } \\
2004\end{array}$ & $\begin{array}{l}(3) \\
\text { Probit } \\
2009\end{array}$ & $\begin{array}{l}(4) \\
\text { Margins } \\
2009\end{array}$ & $\begin{array}{l}(5) \\
\text { Probit } \\
2014\end{array}$ & $\begin{array}{l}(6) \\
\text { Margins } \\
2014\end{array}$ \\
\hline $\begin{array}{l}\text { Firm's revenue from } \\
\text { value-added } \\
\text { [logvadded] } \\
\text { Firm's output } \\
\text { [logouput] }\end{array}$ & $\begin{array}{l}0.206 * * * \\
(0.0487) \\
0.235 * * * \\
(0.0472)\end{array}$ & $\begin{array}{l}0.0538 * \star * \\
(0.0127) \\
0.0613 * \star \star \\
(0.0123)\end{array}$ & $\begin{array}{l}0.187 \star \star \star \\
(0.0472) \\
0.112 \star \star \\
(0.0451)\end{array}$ & $\begin{array}{l}0.0402 \star \star \star \\
(0.0102) \\
0.0242 \star \star \\
(0.00971)\end{array}$ & $\begin{array}{l}0.415 * * * \\
(0.0415) \\
0.00527 \\
(0.0420)\end{array}$ & $\begin{array}{l}0.117 * \star \star \\
(0.0117) \\
0.00148 \\
(0.0118)\end{array}$ \\
\hline $\begin{array}{l}\text { Number of labor } \\
\text { [loglabornum] }\end{array}$ & $\begin{array}{l}-0.0854 * * \\
(0.0358)\end{array}$ & $\begin{array}{l}-0.0223 * \star \\
(0.00934)\end{array}$ & $\begin{array}{l}0.0320 \\
(0.0334)\end{array}$ & $\begin{array}{l}0.00690 \\
(0.00720)\end{array}$ & $\begin{array}{l}-0.177 * \star \star \\
(0.0288)\end{array}$ & $\begin{array}{l}-0.0499 * * \star \\
(0.00811)\end{array}$ \\
\hline $\begin{array}{l}\text { Cost of electricity } \\
\text { [logepurc] }\end{array}$ & $\begin{array}{l}0.0305 * \\
(0.0156)\end{array}$ & $\begin{array}{l}0.00798 * \\
(0.00408)\end{array}$ & $\begin{array}{l}0.0592 * \star * \\
(0.0141)\end{array}$ & $\begin{array}{l}0.0128 * * * \\
(0.00303)\end{array}$ & $\begin{array}{l}0.0731 * \star \star \\
(0.0113)\end{array}$ & $\begin{array}{l}0.0206 * * \star \\
(0.00318)\end{array}$ \\
\hline $\begin{array}{l}\text { Human Development } \\
\text { Index [hdi] }\end{array}$ & $\begin{array}{l}-0.731 * * \\
(0.292)\end{array}$ & $\begin{array}{l}-0.191 * * \\
(0.0762)\end{array}$ & $\begin{array}{l}0.0229 \\
(0.0191)\end{array}$ & $\begin{array}{l}0.00493 \\
(0.00412)\end{array}$ & $\begin{array}{l}-0.0779 * \\
(0.0404)\end{array}$ & $\begin{array}{l}-0.0219 * \\
(0.0114)\end{array}$ \\
\hline $\begin{array}{l}\text { log of electricity } \\
\text { capacity }\end{array}$ & $\begin{array}{l}-41.47 * * \\
(16.29)\end{array}$ & $\begin{array}{l}-10.84 * \star \\
(4.257)\end{array}$ & $\begin{array}{l}-1.069 * \\
(0.566)\end{array}$ & $\begin{array}{l}-0.230 * \\
(0.122)\end{array}$ & $\begin{array}{l}-15.56 * \star \star \\
(5.980)\end{array}$ & $\begin{array}{l}-4.383 * \star \star \\
(1.684)\end{array}$ \\
\hline $\begin{array}{l}\text { Density of population } \\
\text { [logdensity] }\end{array}$ & $\begin{array}{l}12.78 * * \\
(5.202)\end{array}$ & $\begin{array}{l}3.339 * * \\
(1.360)\end{array}$ & $\begin{array}{l}-0.118 \\
(0.237)\end{array}$ & $\begin{array}{l}-0.0254 \\
(0.0510)\end{array}$ & $\begin{array}{l}3.460 * * \\
(1.632)\end{array}$ & $\begin{array}{l}0.975 * * \\
(0.460)\end{array}$ \\
\hline $\begin{array}{l}\text { Regional GDP } \\
\text { [logrgdp] }\end{array}$ & $\begin{array}{l}27.23 * * \\
(10.68)\end{array}$ & $\begin{array}{l}7.117 \star \star \\
(2.792)\end{array}$ & $\begin{array}{l}0.476 \\
(0.486)\end{array}$ & $\begin{array}{l}0.103 \\
(0.105)\end{array}$ & $\begin{array}{l}16.07 * \star \star \\
(5.947)\end{array}$ & $\begin{array}{l}4.527 * \star \star \\
(1.675)\end{array}$ \\
\hline $\begin{array}{l}\text { Agriculture \& } \\
\text { Plantation [sectora] }\end{array}$ & $\begin{array}{l}0.130 * * * \\
(0.0459)\end{array}$ & $\begin{array}{l}0.0339 * \star \star \\
(0.0120)\end{array}$ & $\begin{array}{l}0.149 * \star \star \\
(0.0464)\end{array}$ & $\begin{array}{l}0.0322 * \star \star \\
(0.00998)\end{array}$ & $\begin{array}{l}0.216 * * * \\
(0.0413)\end{array}$ & $\begin{array}{l}0.0609 * \star \star \\
(0.0116)\end{array}$ \\
\hline $\begin{array}{l}\text { Chemical, Metal, \& } \\
\text { Mining Processing } \\
\text { [sectorb] } \\
\text { Food, Drink, and } \\
\text { Tobacco [sectorc] }\end{array}$ & $\begin{array}{l}0.0280 \\
(0.0441) \\
0.0955 * * \\
(0.0461)\end{array}$ & $\begin{array}{l}0.00732 \\
(0.0115) \\
0.0250 * \star \\
(0.0121)\end{array}$ & $\begin{array}{l}0.100 * \star \\
(0.0444) \\
0.126 * * \star \\
(0.0459)\end{array}$ & $\begin{array}{l}0.0216 * * \\
(0.00957) \\
0.0270 * * * \\
(0.00988)\end{array}$ & $\begin{array}{l}0.0492 \\
(0.0385) \\
0.0845 * \star \\
(0.0424)\end{array}$ & $\begin{array}{l}0.0139 \\
(0.0109) \\
0.0238 * \star \\
(0.0119)\end{array}$ \\
\hline $\begin{array}{l}\text { Textile and Wearing } \\
\text { Industry [sectord] }\end{array}$ & $\begin{array}{l}-0.153 * * * \\
(0.0483)\end{array}$ & $\begin{array}{l}-0.0400 * * * \\
(0.0126)\end{array}$ & $\begin{array}{l}-0.172 * * * \\
(0.0490)\end{array}$ & $\begin{array}{l}-0.0370 * * * \\
(0.0105)\end{array}$ & $\begin{array}{l}0.0325 \\
(0.0407)\end{array}$ & $\begin{array}{l}0.00915 \\
(0.0115)\end{array}$ \\
\hline $\begin{array}{l}\text { Others Sector } \\
\text { [sectore] }\end{array}$ & $\begin{array}{l}-0.228 * * * \\
(0.0766)\end{array}$ & $\begin{array}{l}-0.0595 * \star \star \\
(0.0200)\end{array}$ & $\begin{array}{l}0.0351 \\
(0.0685)\end{array}$ & $\begin{array}{l}0.00757 \\
(0.0147)\end{array}$ & $\begin{array}{l}0.0536 \\
(0.0506)\end{array}$ & $\begin{array}{l}0.0151 \\
(0.0143)\end{array}$ \\
\hline Constant & $\begin{array}{l}8.370 * \\
(4.622)\end{array}$ & & $\begin{array}{l}-3.181 * * * \\
(0.928)\end{array}$ & & $\begin{array}{l}-43.59 * * \star \\
(15.05)\end{array}$ & \\
\hline $\begin{array}{l}\text { Observations } \\
\text { Prob > chi2 } \\
\text { Pseudo R2 }\end{array}$ & $\begin{array}{l}18,042 \\
0 \\
0.0936\end{array}$ & 18,042 & $\begin{array}{l}22,141 \\
0 \\
0.0931\end{array}$ & 22,141 & $\begin{array}{l}22,564 \\
0 \\
0.0862\end{array}$ & 22,564 \\
\hline
\end{tabular}




\subsection{Year effect analysis}

To estimate the year effect on the dataset, there are three steps that have been employed. Firstly, I add each of dataset with the year variable information, then all three datasets appended into a single dataset. To regress the combined datasets, it uses i.year as a dummy generator for year variable. The dataset in 2004 become the baseline of the dummy setting.

The result in the table 9 depicts that the year effect in the linear, probit, and marginal effect react the similar way in each year from 2004, 2009 and 2014. Using the year 2004 as the baseline, it shows that in 2009, the number of industries havefuel or using the self-generated electricity decreases $6.3 \%$ in 2009 if compared to 2004 . Both result in the linear and marginal effect show a similar result with strong significant result $(\mathrm{p}<0.01)$ in all dummy variables.

Table 9. Regression result on year effect

\begin{tabular}{|c|c|c|c|}
\hline & $(1)$ & (2) & (3) \\
\hline VARIABLES & Linear & Probit & Margins \\
\hline \multirow[t]{2}{*}{ year $=2009$} & $-0.0630 * * *$ & $-0.266 * * *$ & $-0.0683 * * *$ \\
\hline & $(0.00386)$ & $(0.0158)$ & $(0.00411)$ \\
\hline \multirow[t]{2}{*}{ year $=2014$} & $-0.0357 \star \star \star *$ & $-0.143 * * *$ & $-0.0389 * * *$ \\
\hline & $(0.00434)$ & $(0.0170)$ & $(0.00464)$ \\
\hline \multirow[t]{2}{*}{ Constant } & $-0.481 * \star \star$ & $-3.570 * \star \star$ & \\
\hline & $(0.0155)$ & $(0.0632)$ & \\
\hline
\end{tabular}

Standard errors in parentheses

$\star * \star p<0.01, * * \mathrm{p}<0.05, * \mathrm{p}<0.1$

In 2014, the year effect of the regression estimation also shows a decreasing result even though the value not as big as the effect in 2009. It reduces about $3.6 \%$ in the linear estimation and $3.9 \%$ in probit's marginal effect estimation.

The reason behind this trend could be because of there are economic crisis that happen in 2008 until 2009. The industries tried to reduced their expenditure including the gasoline and diesel fuel cost by optimising the available electricity connection. Thus, these activities create a number of firm that self-generated become lower than previous year of observation.

\subsection{Robustness test by capital estimation variable}

Robustness checking examines the uncertainty of the models and assesses whether the estimated effects of interest variables are responsive to changes in model designs. To check the robustness of the model, first, we can add a new variable that already available. The variable capital estimation shows the estimation of the capital value of the firm based on the current exchange value. There is a reason why the capital variable was not included in the main model because of the number of observations of this variable as much as other variables.

Table 10 shows the marginal effect of model one with different datasets. For results one and two, it uses the dataset 2004. Their slight differences from regression without capital 
and with capital variable, especially form the number of labor (loglabornum), chemical, metal mining variable (sectorc), and in the other sector (sectore) variables. For dataset 2009, the result only indicates a difference in logvalueadded variable. For dataset 2014, the differences appear in the number of labor (loglabornum) and the cost of electricity (loepurc). However, most of the variables show a similar trend. The difference that appears between two results could occur due to the number of capital observation that limited, which lead to decrease the regressed observation. From the result, it can be concluded that the addition of capital in the model not changing the overall result; thus, it can be said that the model could explain the data perfectly.

Table 10. Result of robustness using capital variable

\begin{tabular}{|c|c|c|c|c|c|c|}
\hline VARIABLES & $\begin{array}{c}(1) \\
\text { Margins } \\
2004 \\
\end{array}$ & $\begin{array}{c}\text { (2) } \\
\text { w/ capital }\end{array}$ & $\begin{array}{c}(3) \\
\text { Margins } \\
2009 \\
\end{array}$ & $\begin{array}{c}\text { (4) } \\
\text { w/ capital } \\
\end{array}$ & $\begin{array}{c}(5) \\
\text { Margins } \\
2014 \\
\end{array}$ & $\begin{array}{c}\text { (6) } \\
\text { w/ capital } \\
\end{array}$ \\
\hline $\begin{array}{l}\text { Firm's revenue from value- } \\
\text { added [logvadded] }\end{array}$ & $\begin{array}{c}0.0522 * * * \\
(0.0127)\end{array}$ & $\begin{array}{l}0.0215^{\star} \\
(0.0127)\end{array}$ & $\begin{array}{c}0.0402 * * * \\
(0.0102)\end{array}$ & $\begin{array}{c}-0.00360 \\
(0.0101)\end{array}$ & $\begin{array}{l}0.117 * * \star \\
(0.0117)\end{array}$ & $\begin{array}{l}0.00409 \\
(0.0399)\end{array}$ \\
\hline Firm's output [logouput] & $\begin{array}{l}0.0640 * \star * \\
(0.0124)\end{array}$ & $\begin{array}{c}0.0192 \\
(0.0123)\end{array}$ & $\begin{array}{l}0.0242 * \star \\
(0.00971)\end{array}$ & $\begin{array}{l}0.0264 * * * \\
(0.00951)\end{array}$ & $\begin{array}{l}0.00148 \\
(0.0118)\end{array}$ & $\begin{array}{c}0.0484 \\
(0.0420)\end{array}$ \\
\hline Nur & $\begin{array}{l}-0.0235 * \star \\
(0.00935)\end{array}$ & $\begin{array}{l}0.0623 * * * \\
(0.0103)\end{array}$ & $\begin{array}{c}0.00690 \\
(0.00720)\end{array}$ & $\begin{array}{l}0.0530 * * * \\
(0.00821)\end{array}$ & $\begin{array}{l}-0.049 * * * \\
(0.00811)\end{array}$ & $\begin{array}{l}0.0526 * \\
(0.0276)\end{array}$ \\
\hline Cost of electricity [logepurc] & $\begin{array}{l}0.00955 * * \\
(0.00408)\end{array}$ & $\begin{array}{l}0.000475 \\
(0.00426)\end{array}$ & $\begin{array}{l}0.0128 * * * \\
(0.00303)\end{array}$ & $\begin{array}{c}0.00283 \\
(0.00334)\end{array}$ & $\begin{array}{l}0.0206 * \star * \\
(0.00318)\end{array}$ & $\begin{array}{r}-0.0278 * x \\
(0.0118)\end{array}$ \\
\hline $\begin{array}{l}\text { log of total capital estimation, } \\
\text { based on current value }\end{array}$ & & $\begin{array}{l}0.0339 * * * \\
(0.00511)\end{array}$ & & $\begin{array}{l}0.0245 * * * \\
(0.00398)\end{array}$ & & $\begin{array}{l}0.00466 \\
(0.0105)\end{array}$ \\
\hline Sumatra island [island1] & $\begin{array}{l}0.102 * * * \\
(0.0101)\end{array}$ & $\begin{array}{l}0.108 * * \star \\
(0.0100)\end{array}$ & $\begin{array}{l}0.128 * * * \\
(0.00715)\end{array}$ & $\begin{array}{l}0.123 * * * \\
(0.00731)\end{array}$ & $\begin{array}{l}0.177 * \star \star \\
(0.00890)\end{array}$ & $\begin{array}{l}0.107 * * * \\
(0.0346)\end{array}$ \\
\hline Kali & $\begin{array}{l}0.148 * * * \\
(0.0212)\end{array}$ & $\begin{array}{l}0.156 * * * \\
(0.0202)\end{array}$ & $\begin{array}{l}0.204 * * * \\
(0.0180)\end{array}$ & $\begin{array}{l}0.182 * * * \\
(0.0175)\end{array}$ & $\begin{array}{l}0.247 * * * \\
(0.0209)\end{array}$ & $\begin{array}{l}0.218 * * \\
(0.0916)\end{array}$ \\
\hline Sulawesi island [island3] & $\begin{array}{l}0.101 * * * \\
(0.0164)\end{array}$ & $\begin{array}{l}0.0624 * * * \\
(0.0169)\end{array}$ & $\begin{array}{l}0.146^{\star * \star} \\
(0.0136)\end{array}$ & $\begin{array}{l}0.147 * * * \\
(0.0129)\end{array}$ & $\begin{array}{l}0.107 * \star \star \\
(0.0163)\end{array}$ & $\begin{array}{l}0.177 * \star * \\
(0.0673)\end{array}$ \\
\hline $\begin{array}{l}\text { Papua, Nusa Tenggara, Maluku } \\
\text { island [island4] }\end{array}$ & $\begin{array}{l}0.198 * * * \\
(0.0243)\end{array}$ & $\begin{array}{l}0.128 * \star \star \\
(0.0268)\end{array}$ & $\begin{array}{l}0.153 * * * \\
(0.0191)\end{array}$ & $\begin{array}{l}0.118 * * * \\
(0.0175)\end{array}$ & $\begin{array}{l}0.180 * * * \\
(0.0243)\end{array}$ & $\begin{array}{l}0.258 * \\
(0.153)\end{array}$ \\
\hline $\begin{array}{l}\text { Agriculture \& Plantation } \\
\text { [sectora] }\end{array}$ & $\begin{array}{l}0.0233 * \\
(0.0120)\end{array}$ & $\begin{array}{l}0.0423^{* * *} \\
(0.0137)\end{array}$ & $\begin{array}{l}0.0322 * \star \star \\
(0.00998)\end{array}$ & $\begin{array}{l}0.0268 * * \\
(0.0115)\end{array}$ & $\begin{array}{l}0.0609 * * * \\
(0.0116)\end{array}$ & $\begin{array}{l}0.122 * * * \\
(0.0427)\end{array}$ \\
\hline $\begin{array}{l}\text { Chemical, Metal, \& Mining } \\
\text { Processing [sectorb] }\end{array}$ & $\begin{array}{l}-0.00290 \\
(0.0115)\end{array}$ & $\begin{array}{l}0.0481^{* * *} \\
(0.0133)\end{array}$ & $\begin{array}{l}0.0216 * * \\
(0.00957)\end{array}$ & $\begin{array}{c}0.0140 \\
(0.0112)\end{array}$ & $\begin{array}{l}0.0139 \\
(0.0109)\end{array}$ & $\begin{array}{l}0.0690 * \\
(0.0360)\end{array}$ \\
\hline $\begin{array}{l}\text { Food, Drink, and Tobacco } \\
\text { [sectorc] }\end{array}$ & $\begin{array}{c}0.0154 \\
(0.0121)\end{array}$ & $\begin{array}{l}0.0458 * * * \\
(0.0138)\end{array}$ & $\begin{array}{l}0.0270 * * * \\
(0.00988)\end{array}$ & $\begin{array}{l}0.0223 * * \\
(0.0113)\end{array}$ & $\begin{array}{l}0.0238 * * \\
(0.0119)\end{array}$ & $\begin{array}{l}0.0910 * * \\
(0.0415)\end{array}$ \\
\hline $\begin{array}{l}\text { Textile and Wearing Industry } \\
\text { [sectord] }\end{array}$ & $\begin{array}{l}-0.055 * * * \\
(0.0125)\end{array}$ & $\begin{array}{l}-0.0326 * * \\
(0.0146)\end{array}$ & $\begin{array}{l}-0.037 * * * \\
(0.0105)\end{array}$ & $\begin{array}{l}-0.036 * * * \\
(0.0121)\end{array}$ & $\begin{array}{l}0.00915 \\
(0.0115)\end{array}$ & $\begin{array}{l}-0.0274 \\
(0.0435)\end{array}$ \\
\hline Others Sector [sectore] & $\begin{array}{l}-0.072 * * * \\
(0.0200)\end{array}$ & $\begin{array}{c}0.0119 \\
(0.0210)\end{array}$ & $\begin{array}{l}0.00757 \\
(0.0147)\end{array}$ & $\begin{array}{c}0.0159 \\
(0.0165)\end{array}$ & $\begin{array}{c}0.0151 \\
(0.0143)\end{array}$ & $\begin{array}{c}0.0634 \\
(0.0529)\end{array}$ \\
\hline Observations & 18,042 & 12,767 & 22,141 & 14,546 & 22,564 & 1,429 \\
\hline
\end{tabular}

Standard errors in parentheses

$* * * \mathrm{p}<0.01, * * \mathrm{p}<0.05, * \mathrm{p}<0.1$ 


\subsection{Robustness test by firm's income}

Another method to check the robustness of the model by the income, the dataset firstly divided into four different groups, which are quantile one until quantile four. These groups split according to the number of incomes that proxied by value-added. Then, it assigns as low income for groups one and two, and high income for group three and four. Finally, it applies to all year datasets.

Table 11. Classification summary based on income

\begin{tabular}{lllll}
\hline \multirow{2}{*}{ Group } & \multirow{2}{*}{ Quantile } & \multicolumn{3}{c}{ Mean/Freq } \\
\cline { 3 - 5 } & & \multicolumn{1}{c}{2004} & 2009 & 2014 \\
\hline \multirow{2}{*}{ Low income } & 1 & $137351.23 / 5172$ & $228176.83 / 6117$ & $586942.79 / 6133$ \\
& 2 & $489633.04 / 5171$ & $779268.79 / 6117$ & $2378774.2 / 6136$ \\
High income & 3 & $2125687 / 5172$ & $2985966.5 / 6117$ & $9252364.8 / 6128$ \\
& 4 & $66668022 / 5170$ & $126900000 / 6117$ & $263300000 / 6132$ \\
\hline
\end{tabular}

The robustness result shows that the difference in income of the industry does not have a significant impact on the policy to change the source of electricity. The table displays the data from both high and low-income companies where they tend to do a similar reaction with the average of the industry. While for high-income industries, they choose otherwise. It means that for industries with higher-income, an increase in electricity cost will lead to change the probability of using the grid cost at $2.9 \%$.

The robustness shows that in the characteristic variables such as value-added income (logvadded), output (logoutput), number of labor (loglabornum), and cost of electricity (logepurc) variables shows a slight difference in the slope and magnitude of the number of labor and cost of electricity variables. For island characters, there were no differences between the average marginal effect and the high and lower-income industries. While for sector character variables, there is one difference of magnitude in the, but it does not show a significant in pvalue.

\subsection{Robustness test by firm's output}

For robustness tests by output, the preparation almost similar to the robustness test by value-added/income. The dataset firstly divided into four different groups, which are quantile one until quantile four. These groups split based on the size of income that proxied by value-added. Then, it assigns as low income for groups one and two, and high income for group three and four. Finally, it applies to all year datasets.

Table 12. Classification summary based on firm's output

\begin{tabular}{lcccc}
\hline \multirow{2}{*}{ Firm Group } & \multirow{2}{*}{ Quantile } & \multicolumn{4}{c}{ Mean/Freq } \\
\cline { 3 - 5 } & & 2004 & 2009 & 2014 \\
\hline \multirow{2}{*}{ Low output } & 1 & $331580.99 / 5172$ & $543876.07 / 6120$ & $1402586.9 / 6135$ \\
& 2 & $1358773.5 / 5173$ & $2023117.7 / 6114$ & $5702494.5 / 6130$ \\
\multirow{2}{*}{ High output } & 3 & $6179002.4 / 5169$ & $8265935.9 / 6117$ & $23474218 / 6132$ \\
& 4 & $182800000 / 5171$ & $316300000 / 6117$ & $560400000 / 6132$ \\
\hline
\end{tabular}


The result shows that the firms with high output show a slightly different policy regarding choosing the source of electricity. For a firm with high output and high electricity bills, they have the probability of generating their electricity. This behavior is normal since the electricity cost is also one of the output components. Other variables that split into two different groups of outcomes show a similar reaction with the result of regression. It means that the model is quite good to validate the issue.

\section{Conclusions}

Firstly, based on the location and industrial sector, most of the firm that established in outer Jawa \& Bali, have a probability of changing their source of electricity from grid to off-grid, especially for the firm in Kalimantan and Papua, Nusa Tenggara, Maluku group. The industries that mainly focus on the agriculture and plantation sectors also show a more substantial probability of converting their power sources.

Second, based on the internal condition of the firm, the result of this study shows gives impact on this changing policy. For manufacture that has a higher output indicates a probability to generate their power source. Similarly, the revenue of the firm also leads to changes in the policy. However, the increasing number of labor will lead the firm to decrease its possible to self-generation of electricity source.

By using the year dummy, the study shows that in 2009 the number of the firms that using self-generated electricity are decreasing larger than other two observation data. It means that the impact of the monetary crisis in Indonesia, especially the increasing of energy prices, also impact to the firm's decision on using the self-generated electricity. It shows that the firm that using the self-generated electricity is decreasing about $6.3 \%$ than in 2004 .

Lastly, by interpreting the socioeconomic factor, the result of the regression gives information about the condition of the outside of the firm such as the labor quality, regional GDP, and the capacity of the electricity push the firm to evaluate the policy to change the source of electricity. From the HDI interpretation, we can conclude that a better quality of labor's life, it will drive the firm to keep using the power from PLN's grid. The other socioeconomics factor is regional density. It implies that the denser the island is, the smaller the chance the firm to utilize the self-generated electricity. The regression's result also confirms that the wealthy of the location of the firm's establishment, the more prominent possibility of the firm to use their electricity.

However, taking into account study limitations, I attempt several drawbacks in this research. The detail of the industry's cost of fuel for electricity generation over time is unavailable in the surveys. This unavailability information can lead to two different meanings: the industry used to generate their electricity regularly or temporarily. This information could be vital to differentiate between the fully powered by generators firm or the firm that only use the generator for backup the primary grid. This study was developed based on the assumption that the cost of fuel for electricity generation is frequently.

There also another limitation in choosing the fuel for generating electricity. Due to the limitation of fuel expenditure data, this study assumes variable havefuel made by the availability of diesel fuel and gasoline expenditure. I acknowledge that firms using coal, kerosene, briquette, or another type of fuel could be an indicator of the havefuel variable. 
Another limitation of this study is observatory years, which are limited to 2004, 2009, and 2014 due to data availability. This limitation could be a comprehensive analysis if there is an updated survey to reveal the trend.

\section{References}

ASEAN Center for Energy. (2011). The 3rd ASEAN energy outlook.

Auffhammer, M., \& Wolfram, C. D. (2014). Powering up China: Income distributions and residential electricity consumption. American Economic Review, 104(5), 575-580. https://doi.org/10.1257/aer.104.5.575

Berger, M. C. (1984). Increases in energy prices, costs of production, and plant size. Journal of Economics and Business, 36(3), 345-357. https://doi.org/10.1016/01486195(84)90005-5

Bölük, G., \& Koç, A. A. (2010). Electricity demand of manufacturing sector in Turkey: A translog cost approach. Energy Economics, 32(3), 609-615. https://doi.org/10.1016/j.eneco.2010.01.007

Christensen, L. R., Jorgenson, D. W., \& Lau, L. J. (1973). Transcendental Logarithmic Production Frontiers. The Review of Economics and Statistics, 55(1), 28-45. https://www.jstor.org/stable/ 1927992

Christopoulos, D. K. (2000). The demand for energy in Greek manufacturing. Energy Economics, 22(5), 569-586. https://doi.org/10.1016/So 140-9883(99)00041-9

Doms, M. E., \& Dunne, T. (1995). Energy intensity, electricity consumption, and advanced manufacturing-technology usage. Technological Forecasting and Social Change, 49(3), 297-310. https://doi.org/10.1016/0040-1625(95)00055-F

Dong, X. Y., \& Hao, Y. (2018). Would income inequality affect electricity consumption? Evidence from China. Energy, 142, 215-227. https://doi.org/10.1016/j.energy.2017.10.027

Mirnezami, S. R. (2014). Electricity inequality in Canada: Should pricing reforms eliminate subsidies to encourage efficient usage? Utilities Policy, 31, 36-43. https://doi.org/10.1016/j.jup.2014.08.001

Moyo, B. (2012). Do Power Cuts Affect Productivity? A Case Study Of Nigerian Manufacturing Firms. International Business \& Economics Research Journal (IBER), 11(10), 1163. https://doi.org/10.19030/iber.v11i10.7262

Mulyanto, J., Kunst, A. E., \& Kringos, D. S. (2019). Geographical inequalities in healthcare utilisation and the contribution of compositional factors: A multilevel analysis of 497 districts in Indonesia. Health and Place, 60(August), 102236. https://doi.org/10.1016/j.healthplace.2019.102236

Ribó-Pérez, D., Van der Weijde, A. H., \& Álvarez-Bel, C. (2019). Effects of self-generation in imperfectly competitive electricity markets: The case of Spain. Energy Policy, 133(February). https://doi.org/10.1016/j.enpol.2019.110920 
Roemer, J. E., \& Trannoy, A. (2015). Equality of Opportunity. In Handbook of Income Distribution (1st ed., Vol. 2). Elsevier B.V. https://doi.org/10.1016/B978-0-44459428-0.00005-9

Sambodo, M. T., \& Novandra, R. (2019). The state of energy poverty in Indonesia and its impact on welfare. Energy Policy, 132(October 2018), 113-121. https://doi.org/10.1016/j.enpol.2019.05.029

Sarkodie, S. A., \& Adams, S. (2020). Electricity access, human development index, governance and income inequality in Sub-Saharan Africa. Energy Reports, 6, 455466. https://doi.org/10.1016/j.egyr.2020.02.009

Shi, X. (2019). Inequality of opportunity in energy consumption in China. Energy Policy, 124(November 2018), 371-382. https://doi.org/10.1016/j.enpol.2018.09.029

Wu, K. Y., Huang, Y. H., \& Wu, J. H. (2018). Impact of electricity shortages during energy transitions in Taiwan. Energy, 151(2018), 622-632. https:// doi.org/10.1016/j.energy.2018.03.049

Yoo, S. H., \& Kim, Y. (2006). Electricity generation and economic growth in Indonesia. Energy, 31(14), 2890-2899. https://doi.org/10.1016/j.energy.2005.11.018 